\title{
Allogeneic Hematopoietic Stem Cell Transplantation in Extranodal Natural Killer/T-cell Lymphoma
}

\author{
Ekstranodal Doğal Öldürücü/T-hücreli Lenfomada Allojeneik Hematopoetik Hücre \\ Transplantasyonu
}

\author{
(D) Yin-yin Peng1, (D) Yi-ying Xiong1, (D) Li-xia Zhang1, (D) Jing Wang1, (D) Hong-bin Zhang1, (D) Qing Xiao1, (D) Shu-liang Guo² \\ ${ }^{1}$ First Affiliated Hospital of Chongqing Medical University, Department of Hematology, Chongqing, China \\ ${ }^{2}$ First Affiliated Hospital of Chongqing Medical University, Department of Respiratory Medicine, Chongqing, China
}

\section{Abstract}

Objective: Extranodal NK/T-cell lymphoma (ENKL) is aggressive and resistant to chemotherapy and radiotherapy. Allogeneic hematopoietic stem cell transplantation (allo-HSCT) is a potentially curative treatment for high-risk lymphomas owing to its associated graft-versus-lymphoma (GVL) effect. However, its application to ENKL is limited. We aim to summarize the characteristics of allo-HSCT for ENKL and, more importantly, evaluate whether allo-HSCT could offer any benefits for ENKL

Materials and Methods: A systematic review and data analysis were performed to evaluate the performance of allo-HSCT in the treatment of ENKL using studies obtained from PubMed, Medline, and Embase from January 2000 to December 2019 in the English language.

Results: A total of 136 cases from 17 eligible publications were included in this study. It was found that after allo-HSCT, with an average follow-up time of 34 months (range: 1-121 months), $37.5 \%$ (52) of 136 patients had acute graft-versus-host disease (GVHD) and 31.6\% (43) had chronic GVHD. Furthermore, 35.3\% (48) of the patients were reported to have relapsed, but 2 of those relapsed only locally and achieved complete remission (CR) again with additional irradiation, chemotherapy, and donor lymphocyte infusions for one and rapid tapering and discontinuation of cyclosporine for the other, earning more than one year of extra survival. Finally, of the 136 patients, 51.5\% (70) died because of primary disease progression (42.9\%), infection (20.0\%), GVHD (11.4\%), organ failure (7.1\%), hemorrhage (4.3\%), and other causes (not specified/unknown) (14.3\%).

Conclusion: Allo-HSCT may be a treatment option for advanced or relapsed/refractory ENKL, but its role still requires more rigorous future studies.

Keywords: Extranodal NK/T-cell lymphoma, Chemotherapy, Radiotherapy, Allogeneic hematopoietic stem cell transplantation

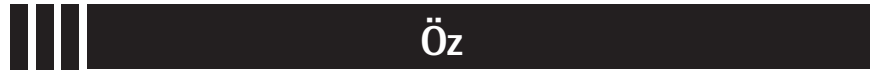

Amaç: Ekstranodal NK/T-hücreli lenfoma (ENKL) agresiftir ve kemoterapi ve radyoterapiye dirençlidir. Allojenik hematopoetik kök hücre transplantasyonu (allo-HSCT), ilişkili graft-lenfoma (GVL) etkisi nedeniyle, yüksek riskli lenfomalara yönelik potansiyel olarak iyileştirici bir tedavidir. Bununla birlikte, ENKL'ye uygulanması sınırlıdır. Bu çalışmada ENKL için allo-HSCT'nin/AHKHN'nin özelliklerini özetlemeyi ve daha da önemlisi allo-HSCT'nin ENK için herhangi bir fayda sağlayıp sağlamayacağını değerlendirmeyi amaçlıyoruz.

Gereç ve Yöntemler: Ocak 2000'den Aralık 2019'a kadar İngilizce dilinde PubMed, Medline ve Embase literatürleri kullanılarak allo-HSCT'nin ENKL'ye performansını değerlendirmek için sistematik bir inceleme ve veri analizi gerçekleştirildi.

Bulgular: Bu çalışmaya 17 uygun yayından toplam 136 olgu dahil edildi. 1) allo-HSCT'den sonra, 34 aylık ortalama takip süresine göre (aralık: 1-121 ay), 136 hastanın \%37,5'inde (52) akut graft-versushost hastalığı (GVHD), \%31,6'sında (43) kronik GVHD vardı; 2) rapor edildiğinde, hastaların \%35,3'ünde (48) relaps vardı, ancak bunlardan ikisi sadece lokal olarak nüks etti ve bunlardan birine ek ışınlama, kemoterapi, donör lenfosit infüzyonu ile tekrar tam remisyon (CR) sağladı, diğerine siklosporinin hızlı azaltılması ve kesilmesi bir yıldan fazla ekstra sağkalım kazandırdı; 3) 136 hastanın \%51,5'i (70) primer hastalık ilerlemesi $(\% 42,9)$, enfeksiyon $(\% 20,0)$, GVHD $(\% 11,4)$, organ yetmezliği $(\% 7,1)$, kanama $(\% 4,3)$ ve diğerleri (belirtilmedi/bilinmiyor) $(\% 14,3)$ nedeniyle öldü.

Sonuç: Allo-HSCT, ilerlemiş veya nükseden/refrakter ENKL için bir tedavi seçeneği olabilir, ancak rolü hala daha titiz gelecek çalışmaları gerektirmektedir.

Anahtar Sözcükler: Ekstranodal NK/T-hücreli lenfoma, Kemoterapi, Radyoterapi, Allojeneik hematopoetik kök hücre nakli

- Copyright 2021 by Turkish Society of Hematology

Turkish Journal of Hematology, Published by Galenos Publishing House

口 University, Department of Hematology, Chongqing, China

Phone : 86-15123312126

E-mail : pengyinyin802320@163.com ORCID: orcid.org/0000-0002-7978-4826 


\section{Introduction}

Natural killer cell tumors are categorized as extranodal NK/Tcell lymphoma (ENKL), aggressive NK-cell leukemia and chronic NK-cell lymphoproliferative disorders according to the 2016 World Health Organization (WHO) classification [1]. Among them, ENKL is relatively more common. ENKLs include both nasal and extra-nasal ENKL categories of disease in the current 2016 WHO classification [2]. It is rarely diagnosed in Western countries but relatively more common in East Asian countries, being closely associated with Epstein-Barr virus (EBV). Pathologically, ENKL shows a highly aggressive clinical behavior. It usually involves the nasal cavity, nasopharynx, upper aerodigestive tract, skin, gastrointestinal tract, or other parts of the body, which have poorer survival. Limited-stage ENKL responds relatively much better to radiotherapy or to concurrent radiation and chemotherapy than advanced or relapsed/refractory ENKL. So far, there is no standard management for relapsed or refractory disease.

Although ENKL's clinical features and prognostic factors have been well characterized in the last decades, optimal treatment strategies still remain unclear. The tumor cells lack L-asparagine synthetase and are susceptible to L-asparaginase, which depletes L-asparagine in NK lymphoma cells [1]. Regimens containing L-asparagine were effective for limited-stage ENKL; however, when used in patients with advanced-stage disease, these regimens were not so satisfactory. Some studies showed that the complete remission (CR) rate with the L-asparagine, etoposide, and dexamethasone (AspaMetDex) regimen for patients with advanced-staged disease was 30\%, and the 5-year survival rate with the L-asparagine, vincristine, and dexamethasone (LVD) regimen was only $25 \%[3,4]$. As advanced-stage or relapsed/refractory ENKL is highly progressive and sometimes multidrug-resistant, L-asparaginase-based therapy is still a challenge [5].

Allogeneic hematopoietic stem cell transplantation (allo-HSCT) is a potentially curative treatment for high-risk lymphoma patients owing to its associated graft-versus-lymphoma (GVL) effect. Furthermore, ENKL cells almost invariably express EBV antigens, providing an alloreactive target to enhance the GVL effect [1]. Although allo-HSCT is an effective way to treat hematologic tumors, its applications for ENKL remain limited. Some small series of studies have demonstrated a disease-free survival (DFS) of 30\%-50\%, but with high transplant-related mortality of about 25\% [1,6-9]. Problems still remain: (1) undoubtedly, both infection and acute graft-versus-host disease (GVHD) during allo-HSCT often cause death; (2) the heavy psychological pressure during allo-HSCT is still overwhelming; (3) and, furthermore, human leukocyte antigen (HLA) donors and patients are still hard to match for allo-HSCT. Therefore, in this study we aim to summarize the characteristics of allo-HSCT for ENKL and, more importantly, evaluate whether allo-HSCT could offer any benefits for ENKL.

\section{Materials and Methods}

\section{Literature Review}

We searched PubMed, Medline, and Embase for publications in the English language from January 2000 to December 2019. The following terms were used: "natural killer/T-cell tumors" or "natural killer/T-cell neoplasm" or "natural killer/T-cell lymphoma" or "extranodal natural killer/T-cell lymphoma" or "extranodal natural killer/T-cell lymphoma nasal type" or "angiocentric lymphoma" and "hematopoietic stem cell transplantation" or "transplantation" or "therapy" or "treatment."

\section{Study Selection}

Studies were considered eligible in the analysis if they met the following inclusion criteria: (1) patients were diagnosed with ENKL according to REAL and WHO classifications; (2) patients did not suffer from a second primary malignancy before or together with ENKL; (3) patients were treated with allo-HSCT; (4) studies provided data including overall survival (OS), progression-free survival (PFS), and/or DFS or other markers describing the survival outcome.

Studies that met any of the following criteria were excluded: (1) non-English literature; (2) repeated studies; (3) studies without relevant outcome indicators.

\section{Data Extraction}

Data were extracted by two independent authors and checked by another. Disagreements were resolved in consultation with the third author. For each study, the following information was extracted: (1) basic information such as the author, date, country, patient numbers and characteristics, etc.; (2) specific intervention details; (3) outcome indicators and measures such as OS, PFS, and DFS.

\section{Data Analysis}

The measurement data were expressed in percentages and composition ratios and then the "average age" and "average follow-up time" after allo-HSCT were calculated. The "average age" is only an average value of the "referred ages" of all the references. "Referred age" here means the "mean age" or "median age" in different papers, which are not identical. Theoretically, if all references calculate "mean age" of patients in their case studies, our "average value" of their "referred ages" in this study should equal the mean age of the 136 patients. However, some references calculated "median age" and we had no opportunity to obtain their original data. Thus, we had to take the "median ages" as approximate indicators of the mean ages and finally 
calculate an average value of those indicators. For instance, if we had collected $\mathrm{m}$ references, and if in publication i totally $N_{i}$ patients were reported, and if the paper said the average age (or mean age, or median age) of the $N_{i}$ patients was $A_{i}$, then the "average age" $A$ of all the patients in the $m$ references selected in this study was calculated as follows:

$A=\frac{\sum_{i=1}^{m} N_{i} A_{i}}{\sum_{i=1}^{m} N_{i}}$

The calculation for "average follow-up time" basically follows the same idea as that for "average age." In this study, we only calculated these two "average" values. The percentages (for sex, clinical stage, etc.) in Table 1 and Supplementary Table 1 were all calculated using the original counts from the references.

\section{Results}

\section{Literature Review and Selection}

We searched among the articles available in PubMed, Medline, and Embase. Only 17 eligible articles reporting 136 patients were found in this analysis. The male/female ratio of the 136 patients was 1.6:1 and the average age was 40 years (Supplementary Table 1). The detailed clinical features of the 136 patients are listed in Table 2 and Supplementary Table 1.

\begin{tabular}{|c|c|c|}
\hline Clinical characteristics & & Number (percentage) \\
\hline \multirow{2}{*}{ Sex } & Male & $83(61.1 \%)$ \\
\hline & Female & $53(38.9 \%)$ \\
\hline \multirow{3}{*}{ Clinical stage } & $1 / I I$ & $52(38.2 \%)$ \\
\hline & III/IV & $54(39.7 \%)$ \\
\hline & Others & $30(22.1 \%)$ \\
\hline \multirow{3}{*}{$\begin{array}{l}\text { Disease status at } \\
\text { transplantation }\end{array}$} & CR & $63(46.3 \%)$ \\
\hline & Residual, refractory/relapsed disease & $63(46.3 \%)$ \\
\hline & Unknown & $10(7.4 \%)$ \\
\hline \multirow{2}{*}{ L-asparaginase-containing chemotherapy before allo-HSCT } & Yes & $54(39.7 \%)$ \\
\hline & No/unknown & $82(60.3 \%)$ \\
\hline \multirow{2}{*}{ Radiation before allo-HSCT } & Yes & $48(35.3 \%)$ \\
\hline & No/unknown & $88(64.7 \%)$ \\
\hline \multirow{3}{*}{ Conditioning regimens } & Myeloablative & $76(55.5 \%)$ \\
\hline & Reduced-intensity & $58(42.3 \%)$ \\
\hline & Missing & $3(2.2 \%)$ \\
\hline \multirow{4}{*}{ Source of hematopoietic stem cells } & From peripheral blood stem cell donors & $99(72.3 \%)$ \\
\hline & Bone marrow & $23(16.8 \%)$ \\
\hline & Cord blood & $14(10.2 \%)$ \\
\hline & Not reported clearly & $1(0.7 \%)$ \\
\hline \multirow{5}{*}{ Donor matching } & Matched-related donor & $76(55.5 \%)$ \\
\hline & Matched-unrelated donor & $32(23.4 \%)$ \\
\hline & Umbilical cord blood & $6(4.4 \%)$ \\
\hline & Haploidentical-related donor & $14(10.2 \%)$ \\
\hline & Unknown & $9(6.6 \%)$ \\
\hline \multirow{2}{*}{ GVHD } & Acute GVHD & $52(37.5 \%)$ \\
\hline & Chronic GVHD & $43(31.6 \%)$ \\
\hline \multirow{6}{*}{$\begin{array}{l}\text { Cause of death }(n=70) \\
\text { (corresponding rates in the last column for each cause calculated in terms } \\
\text { of the number and the total deaths, } n=70 \text { ) }\end{array}$} & Primary disease progression & $30(42.9 \%)$ \\
\hline & Infection & $14(20.0 \%)$ \\
\hline & GVHD & $8(11.4 \%)$ \\
\hline & Organ failure & $5(7.1 \%)$ \\
\hline & Hemorrhage & $3(4.3 \%)$ \\
\hline & Other (not specified)/unknown & $10(14.3 \%)$ \\
\hline
\end{tabular}




\section{Status and Treatment before Allo-HSCT}

At initial diagnosis, 38.2\% (52) of the 136 patients had early-stage (I/II) disease, 39.7\% (54) had advanced (III/IV) disease, and the staging of the other $22.1 \%$ (30) was unknown. When receiving allo-HSCT, 46.3\% (63) were in CR without disease, 46.3\% (63) had residual/refractory/relapsed disease, and the status of the other 7.4\% (10) was unknown. Among the 63 patients who were in CR before allo-HSCT, 58.7\% (37) were in $\mathrm{CR}_{1}, 39.7 \%$ (25) were in $\mathrm{CR}_{2}$, and the status of the other 1.6\% (1) was unknown. Before allo-HSCT, 39.7\% (54) of the 136 patients received L-asparaginase-containing chemotherapy and $35.3 \%$ (48) received radiotherapy (Table 1 ).

The 136 patients received a total of 137 successful allo-HSCTs without any graft failure, including one patient who underwent the procedure twice [10]. The patient who underwent treatment twice first received an allogeneic peripheral blood stem cell transplantation (allo-PBSCT) from an HLA-identical donor (younger brother) after myeloablative pretreatment, but 2 months later, he relapsed and had a lymphoma-associated hemophagocytic syndrome. He then received salvage SMILE chemotherapy and high-dose intravenous methylprednisolone; thus, he underwent the second allo-PBSCT from a haplo-identical donor (son) after non-myeloablative (reduced-intensity) pretreatment. Unfortunately, his disease still progressed, and he died of multiple-organ failure [10]. Among the 137
allo-HSCTs, 55.5\% (76) of the donors were matched-related, 23.4\% (32) were matched-unrelated, $10.2 \%$ (14) were haploidentical-related, 4.4\% (6) were umbilical cord blood transplantations, and the other 6.6\% (9) were unknown.

Among the 136 patients, before allo-HSCT 55.5\% (76) received myeloablative conditioning regimens, $42.3 \%$ (58) received reduced-intensity conditioning regimens, and the regimens of the other 2.2\% (3) were unknown. As for the source of the hematopoietic stem cells, 72.3\% (99) were from peripheral blood stem cells, 16.8\% (23) were from bone marrow, and 10.2\% (14) were from cord blood, while the other $0.7 \%$ (1) was unknown.

\section{GVHD}

GVHD prophylaxis for these 136 patients included calcineurin inhibitor (cyclosporine A or tacrolimus), mycophenolate mofetil, short-course methotrexate, and their combinations. At the average follow-up time of 34 months after allo-HSCT, 51 patients (37.5\%) had developed acute GVHD and 43 patients $(31.6 \%)$ had developed chronic GVHD. As the reviewed studies reported, most of these were cases of mild GVHD (grade I or II) (Table 1 and Supplementary Table 1).

\section{Survival}

At the time of the publication of the reviewed studies, 48 patients (35.3\%) had relapsed and 70 patients (51.5\%) had died. Two of the 48 patients with relapsed ENKL were locally

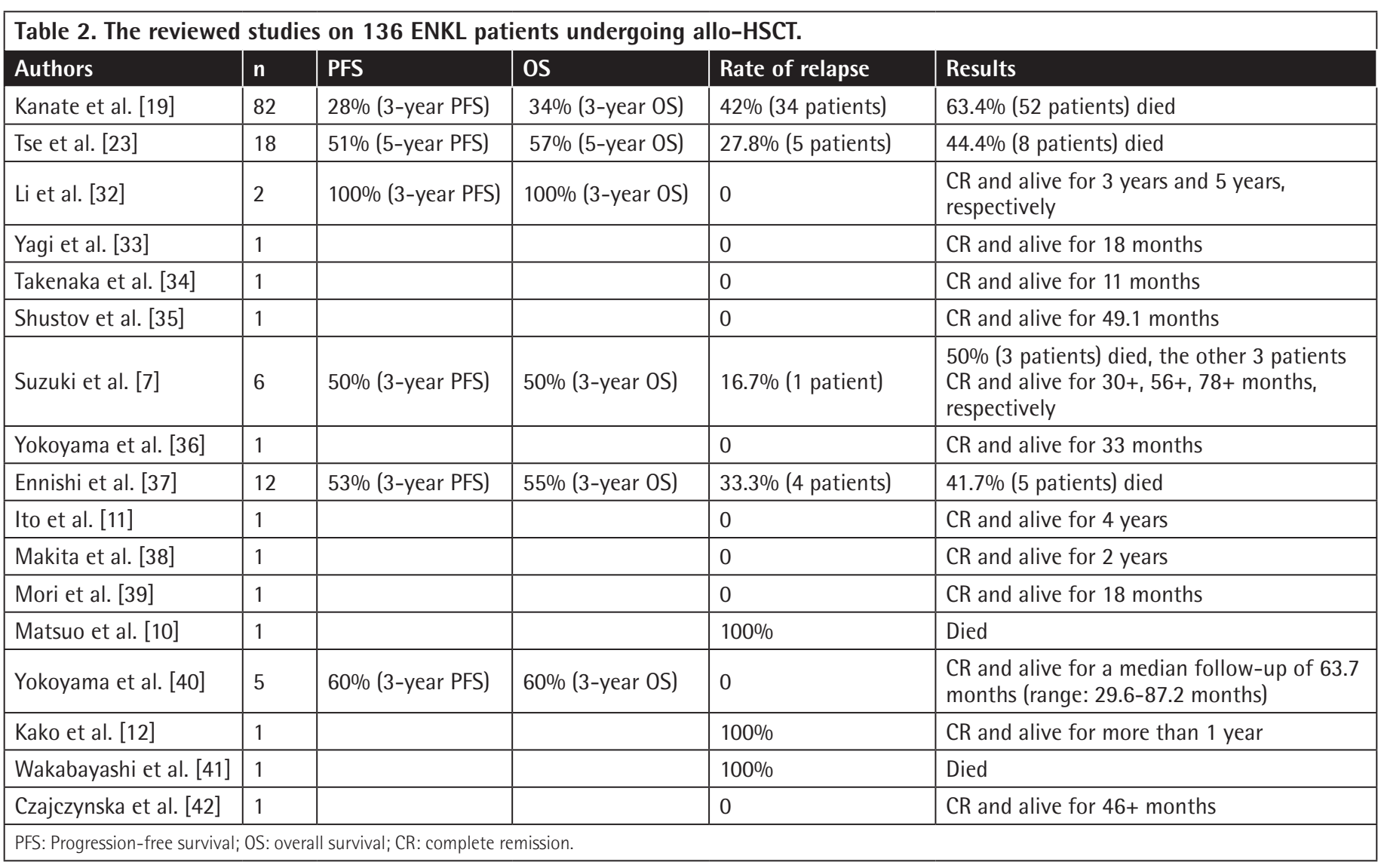


relapsed. One patient received additional irradiation, a course of chemotherapy, and donor lymphocyte infusions [11], while the other one [12] relapsed when her cyclosporine dose was rapidly tapered and discontinued from $80 \mathrm{mg} /$ day, and lesions regressed gradually. These 2 patients achieved and maintained CR again and survived for one additional year. Causes of death included primary disease progression in 30 patients $(42.9 \%)$, infection in 14 patients $(20.0 \%)$, GVHD in 8 patients $(11.4 \%)$, organ failure in 5 patients (7.1\%), hemorrhage in 3 patients (4.3\%), and other unknown reasons in 10 patients (14.3\%) (Table 1).

\section{Discussion}

ENKL is a unique clinical entity characterized by an aggressive clinical course. Both the strategy and the outcome of its treatment depend on disease stage. For patients at lower stages $(I / I I)$, combined chemotherapy and radiation therapy is recommended, which achieves a 5-year OS rate ranging from $42 \%$ to $83 \%$ [13]. In contrast, patients at advanced stages (III/IV) have not been shown to benefit from the addition of radiotherapy and systemic chemotherapy. The overall prognosis of ENKL is poor and its expected 5-year OS is less than 20\% [14]. It must also be noted that, although L-asparaginase-based regimens have shown particularly high activity in ENKL patients, a significant number of ENKL patients still relapse after primary therapy, even with the significant toxicity of these regimens. Therefore, people still have substantial interest in alternate treatment strategies $[3,15,16,17]$. Currently, autologous hematopoietic stem cell transplantation is commonly performed in cases of advanced or relapsed/refractory ENKLs, and allo-HSCT is also reported in some studies.

Allo-HSCT is a potential curative treatment for high-risk lymphoma patients owing to its associated GVL effect. A recent publication by the American Society for Blood and Marrow Transplantation (ASBMT) suggested that allo-HSCT should be limited to advanced-stage and relapsed/refractory ENKL [18]. Recently, several research groups have also investigated the benefit of allo-HSCT in patients with newly diagnosed or relapsed/refractory disease. However, besides case reports, highquality data on the application of allo-HSCT in ENKL are still limited.

Among the 136 patients reviewed in this study, more patients were middle-aged males with advanced-stage ENKL. Before allo-HSCT, only 39.7\% (54) of the 136 patients received L-asparaginase-containing chemotherapy; $35.3 \%$ (48) received radiotherapy; $46.3 \%$ were in $\mathrm{CR}\left(\mathrm{CR}_{1}: 27.2 \%\right.$ $+\mathrm{CR}_{2}: 18.4 \%$ + unknown: $0.7 \%$ ) and another $46.3 \%$ were in partial remission (PR) or had refractory/relapsed disease. More patients received myeloablative conditioning regimens, and more donors for patients receiving allo-HSCT were matched-related. As for the source of hematopoietic stem cells, more were from peripheral blood stem cells. GVHD is unavoidable in allo-HSCT, but, fortunately, most cases were mild GVHD, such as grade I/II. Finally, the calculated overall mortality for the studies in Table 1 was $51.5 \%$, while in a recent large-scale study of 82 ENKL patients, the mortality rate was as high as $63.4 \%$ [19]. The most common reason for death was primary disease progression, still attributed to the highly malignant and aggressive tumor cells.

Clinically, ENKL is characterized by a predominance in young males, is seen in a large proportion as localized stage I and II disease, is refractory to conventional chemotherapy, and is sensitive to radiotherapy [20]. The reported OS varies widely between series. It is known that even limited-stage ENKL has a poor prognosis. The 5-year OS rates with $\mathrm{CHOP}$ and involvedfield radiotherapy in cases of local nasal ENKL were reported as $<50 \%[21,22]$. Some chemotherapy regimens containing L-asparaginase or pegaspargase, such as SMILE, AspaMetDex, and GELOX, have exhibited promising responses. A multicenter analysis from the Asia Lymphoma Study Group [23] reported that patients who had received SMILE chemotherapy before allo-HSCT had significantly better OS and PFS than patients treated with other regimens. However, another study [24] showed that L-asparaginase-containing and L-asparaginaselacking regimens did not yield a significant difference in 2-year OS and PFS for advanced-stage ENKL, while radiotherapy was associated with significantly prolonged survival in OS and PFS in subgroup analysis. As for the 136 patients reviewed in this study, only $39.7 \%$ (54) of them received L-asparaginasecontaining chemotherapy, while $35.3 \%$ (48) received radiotherapy. Thus, if more patients receive L-asparaginasecontaining chemotherapy and radiotherapy before allo-HSCT, it may influence the prognosis, but this needs more verification.

A recent retrospective study from Japan reported the limitations of the new therapeutic strategies and novel regimens, finding almost no improvement in early disease progression and 1-year PFS, while approximately 20\% of patients died or experienced disease relapse [25]. Even worse, some studies reported the relapse rate to be as high as nearly $30 \%$ in early-stage ENKL $[26,27]$. Once an aggressive ENKL tumor develops outside the original site, it can grow rapidly and even disseminate with fever, hemophagocytic syndrome, or disseminated intravascular coagulation. Some neoplasms are also multidrug-resistant, leading to relapsed/refractory cases and seriously affecting the prognosis. Therefore, the prognosis of advanced and relapsed/refractory ENKL is poor and the mortality is high. In this study, the overall mortality rate of the 136 patients was 51.5\% and the main reason for mortality was primary disease progression. There are two main explanations for this mortality. First of all, although the proportions of advanced-stage and early-stage disease were 
close $(39.7 \%$ vs. $38.2 \%)$, the other $22.1 \%$ of cases (unknown disease stage) may also have included some advanced-stage patients. Second, some patients had refractory/relapsed disease before allo-HSCT with poor prognosis. In such cases, the disease is more likely to progress and even lead to death after allo-HSCT. The second leading cause of death after allo-HSCT was infection, followed by GVHD, organ failure, and hemorrhage. Infection and GVHD are still two major causes of death after allo-HSCT for hematological malignancies. The high treatment-related mortality limits its widespread use.

The prognosis of ENKL is relatively poor. Most diagnosed patients survived $<2$ years. It was reported that the overall response rate (ORR) after conventional therapy was 36\% for newly diagnosed stage IV ENKL and was $<10 \%$ for relapsed/ refractory ENKL [28]. In this study of 136 patients, the ORR was $48.5 \%$, higher than that seen among advanced (or relapsed/ refractory) ENKL patients not receiving allo-HSCT. The longest time for maintaining CR after allo-HSCT for these 136 patients was 2617 days. In the follow-up period, only 33.8\% (46) of the 136 patients failed to achieve CR after allo-HSCT, but $35.3 \%$ (48) relapsed again after allo-HSCT. A multicenter analysis from the Asia Lymphoma Study Group reported that the 5-year OS was 57\% and the 5-year PFS was 51\% [23]. A large-scale study reported that no transplant recipient had relapsed in 2 years after transplantation, suggesting potent GVL effects [19]. Therefore, allo-HSCT is still a viable therapy option for a subset of ENKL patients. The most important thing is to reduce the high treatment-related mortality.

However, obviously, the toxicity of the pre-allo-HSCT conditioning regimen and possibly the acute post-allo-HSCT GVHD lead to more deaths. A combined analysis [6] of 28 NK-cell neoplasms patients (22 with ENKL) showed that treatment-related mortality was higher in patients receiving conventional myeloablative stem cell transplantation $(30 \%$ vs. $20 \%)$ than that in patients receiving reducedintensity stem cell transplantation, while the ORRs of the two patient groups had no significant difference (60\% vs. $52 \%)$. However, non-myeloablative conditioning regimens may lead to high relapse rates, GVHD, and non-engraftment, so the role of non-myeloablative HSCT remains undefined. As the GVL effect has not been definitively established for NK-cell lymphoma, the use of non-myeloablative conditioning should be reserved for patients unsuitable for myeloablative regimens in the setting of clinical trials [29]. In these 136 patients, $72.3 \%$ of 137 allo-HSCTs were peripheral HSCTs, perhaps because of collection convenience and the therapy effect being as good as that of bone marrow transplantation. While $10.2 \%$ of these 137 allo-HSCTs were cord blood HSCTs, the applicability of umbilical cord blood HSCT needs to be further defined.
The occurrence of GVHD during allo-HSCT cannot be completely avoided. It was reported [23] that the development of acute GVHD had a significant negative impact on OS but not on PFS. Chronic GVHD had an insignificant impact on survival in univariate analysis, while in multivariate analysis, acute GVHD was no longer a significant factor for OS and PFS. In this study, it has been seen that $37.5 \%$ (51) of the 136 patients had acute GVHD and 31.6\% (43) had chronic GVHD, but the GVHD-induced mortality rate was $11.4 \%$, indicating that the GVHD was generally controllable.

In the authors' own department, we have treated more than 100 ENKL patients, but only 2 such patients underwent allo-HSCT in the past 5 years. Both of those patients were in an advanced stage (IV) of disease. Of the 2 patients, a female patient had PR after receiving CHOP chemotherapy, then achieved CR after treatment with SMILE regimens. Three months later, she underwent allo-PBSCT from an HLA-related sibling. The IBUCY conditioning regimen was used (idarubicin at $12 \mathrm{mg} / \mathrm{m}^{2}$ on days -11 to -9 , busulfan at $0.8 \mathrm{mg} / \mathrm{kg}$ q6h on days -6 to -4 , cyclophosphamide at $50 \mathrm{mg} / \mathrm{kg}$ on days -3 and -2 ). She maintained CR and survived for more than 66 months without any acute or chronic GVHD. The second patient, male, still remained in PR after 4 courses of GLIDE (gemcitabine, ifosfamide, etoposide, dexamethasone, pegaspargase) + methotrexate, and then he received allo-PBSCT from an HLA-related brother, conditioned with FLAG + BUCY (fludarabine at $30 \mathrm{mg} / \mathrm{m}^{2}$ on days -10 to -7 , cytarabine at $2 \mathrm{~g} / \mathrm{m}^{2}$ on days -10 to -7 , busulfan at $0.8 \mathrm{mg} / \mathrm{kg}$ q6h on days -6 to -4 , cyclophosphamide at $50 \mathrm{mg} / \mathrm{kg}$ on days -3 and -2 ). He has now been well for 50 months in CR without acute or chronic GVHD.

\section{Limitations and Conclusion}

Due to the rarity of ENKL and the difficulty of conducting randomized controlled trials, the optimal treatment regimen of ENKL has not yet been determined. Consequently, a heavy selection bias might exist. In patients from isolated case reports, a reporting bias toward successful treatment outcomes is apparent. Finally, as none of the studies included in this study were controlled, the outcome of comparable patients treated with conventional chemotherapy and radiotherapy was not available to judge whether allo-HSCT had affected the outcome. Some important information (like remission status, chemosensitivity, overall survival, Kaplan-Meier analysis, etc.) was not elaborate enough in the available references, and this is a shortcoming of the present study. Based on this limited information, we can conclude that allo-HSCT can be considered an option for ENKL, but it should be limited to cases of advanced or relapsed/refractory ENKL. Novel treatments such as anti-CD30 antibody [30] and programmed death protein ligand 1 [31] were reported to be feasible choices for relapsed/ refractory ENKL, which have been promising in ongoing trials 
to confirm their therapy results and help discover combination therapies.

Acknowledgment: The authors thank the editors of this journal for their help during manuscript preparation.

\section{Ethics}

Ethics Committee Approval: Ethical approval was not required in this study because all cases were collected from published papers.

\section{Authorship Contributions}

Concept: Y.Y.P., H.B.Z., S.L.G.; Design: Y.Y.P., H.B.Z., S.L.G.; Data Collection or Processing: Y.Y.P., H.B.Z., S.L.G.; Analysis or Interpretation: Y.Y.P., Y.Y.X., S.L.G., Q.X.; Literature Search: Y.Y.P., Y.Y.X., L.X.Z., J.W.; Writing: Y.Y.P., Y.Y.X., S.L.G.

Conflict of Interest: No conflict of interest was declared by the authors.

Financial Disclosure: The authors declared that this study received no financial support.

\section{References}

1. Liang R. Advances in the management and monitoring of extranodal NK/Tcell lymphoma, nasal type. Br J Haematol 2009;147:13-21.

2. Kim SJ, Yoon DH, Jaccard A, Chng WJ, Lim ST, Hong H, Park Y, Chang KM, Maeda Y, Ishida F, Shin DY, Kim JS, Jeong SH, Yang DH, Jo JC, Lee GW, Choi CW, Lee WS, Chen TY, Kim K, Jung SH, Murayama T, Oki Y, Advani R, d'Amore F, Schmitz N, Suh C, Suzuki R, Kwong YL, Lin TY, Kim WS. A prognostic index for natural killer cell lymphoma after non-anthracycline-based treatment: a multicentre, retrospective analysis. Lancet Oncol 2016;17:389-400.

3. Jaccard A, Gachard N, Marin B, Rogez S, Audrain M, Suarez F, Tilly H, Morschhauser F, Thieblemont C, Ysebaert L, Devidas A, Petit B, de Leval L, Gaulard P, Feuillard J, Bordessoule D, Hermine 0; GELA and GOELAMS Intergroup. Efficacy of L-asparaginase with methotrexate and dexamethasone (AspaMetDex regimen) in patients with refractory or relapsing extranodal NK/T-cell lymphoma, a phase 2 study. Blood 2011;117:1834-1839.

4. Yong $W$, Zheng $W$, Zhu J, Zhang $Y$, Wang $X$, Xie $Y$, Lin N, Xu B, Lu A, Li J. L-asparaginase in the treatment of refractory and relapsed extranodal NK/T-cell lymphoma, nasal type. Ann Hematol 2009;88:647-652.

5. Tse E, Kwong YL. Management of Advanced NK/T-cell lymphoma. Curr Hematol Malig Rep 2014;9:233-242.

6. Murashige N, Kami M, Kishi $Y$, Kim SW, Takeuchi M, Matsue K, Kanda $Y$, Hirokawa M, Kawabata Y, Matsumura T, Kusumi E, Hirabayashi N, Nagafuji K, Suzuki R, Takeuchi K, Oshimi K. Allogeneic haematopoietic stem cell transplantation as a promising treatment for natural killer-cell neoplasms. Br J Haematol 2005;130:561-567.

7. Suzuki R, Suzumiya J, Nakamura S, Kagami Y, Kameoka Jl, Sakai C, Mukai H, Takenaka K, Yoshino T, Tsuzuki T, Sugimori H, Kawa K, Kodera Y, Oshimi K; NK-cell Tumor Study Group. Hematopoietic stem cell transplantation for natural killer-cell lineage neoplasms. Bone Marrow Transplant 2006;37:425431.

8. Suzuki R, Takeuchi K, Ohshima K, Nakamura S. Extranodal NK/T-cell lymphoma: diagnosis and treatment cues. Hematol Oncol 2008;26:66-72.

9. Sato $E$, Ohga $S$, Kuroda $H$, Yoshiba F, Nishimura M, Nagasawa M, Inoue M, Kawa K. Allogeneic hematopoietic stem cell transplantation for Epstein-
Barr virus-associated T/natural killer-cell lymphoproliferative disease in Japan. Am J Hematol 2008;83:721-727.

10. Matsuo T, Tanaka T, Ichimura K, Meguri Y. Intraocular relapse with hypopyon and retinal infiltrates after chemotherapy and peripheral blood stem cell transplantation for extranodal NK/T-cell lymphoma. J Clin Exp Hematop 2015; 55 : 157-161.

11. Ito $T$, Makishima $H$, Nakazawa $H$, Senoo $Y$, Senoo $N$, Ishida $F$. Donor lymphocyte infusion for extranodal NK/T cell lymphoma, nasal type, relapsed after allogeneic hematopoietic SCT. Bone Marrow Transplant 2011;46:1270-1271.

12. Kako $S$, Izutsu $K$, Oshima $K$, Sato $H$, Kanda $Y$, Motokura $T$, Chiba $S$, Kurokawa M. Regression of the tumor after withdrawal of cyclosporine in relapsed extranodal natural killer/T cell lymphoma following allogeneic hematopoietic stem cell transplantation. Am J Hematol 2007;82:937939.

13. Lee J, Au WY, Park MJ, Suzumiya J, Nakamura S, Kameoka J, Sakai $C$, Oshimi K, Kwong YL, Liang $R$, Yiu $H$, Wong KH, Cheng HC, Ryoo BY, Suh C, Ko YH, Kim K, Lee JW, Kim WS, Suzuki R. Autologous hematopoietic stem cell transplantation in extranodal natural killer/T cell lymphoma: a multinational, multicenter, matched controlled study. Biol Blood Marrow Transplant 2008;14:1356-1364.

14. Shustov A. Controversies in autologous and allogeneic hematopoietic cell transplantation in peripheral T/NK-cell lymphomas. Best Pract Res Clin Haematol 2013;26:89-99.

15. Yamaguchi M, Kwong YL, Kim WS, Maeda $Y$, Hashimoto C, Suh C, Izutsu $K$, Ishida $F$, Isobe $Y$, Sueoka E, Suzumiya J, Kodama $T$, Kimura $H$, Hyo $R$, Nakamura S, Oshimi K, Suzuki R. Phase II study of SMILE chemotherapy for newly diagnosed stage IV, relapsed, or refractory extranodal natural killer (NK)/T-cell lymphoma, nasal type: the NK-Cell Tumor Study Group Study. J Clin Oncol 2011;29:4410-4416.

16. Kwong YL, Kim WS, Lim ST, Kim SJ, Tang T, Tse E, Leung AY, Chim CS. SMILE for natural killer/T-cell lymphoma: analysis of safety and efficacy from the Asia Lymphoma Study Group. Blood 2012;120:2973-2980.

17. Dhawale TM, Shustov AR. Autologous and allogeneic hematopoietic cell transplantation in peripheral T/NK-cell lymphomas: a histology-specific review. Hematol Oncol Clin North Am 2017;31:335-357.

18. Kharfan-Dabaja MA, Kumar $A$, Ayala E, Hamadani M, Reimer P, Gisselbrecht C, d'Amore $F$, Jantunen E, Ishida T, Bazarbachi A, Foss F, Advani R, Fenske TS, Lazarus HM, Friedberg JW, Aljurf M, Sokol L, Tobinai K, Tse E, Burns $\sqcup$, Chavez JC, Reddy NM, Suzuki R, Ahmed S, Nademanee A, Mohty M, Gopal AK, Fanale MA, Pro B, Moskowitz AJ, Sureda A, Perales MA, Carpenter PA, Savani BN. Clinical practice recommendations on indication and timing of hematopoietic cell transplantation in mature T cell and NK/T cell lymphomas: an international collaborative effort on behalf of the Guidelines Committee of the American Society for blood and marrow transplantation. Biol Blood Marrow Transplant 2017;23:1826-1838.

19. Kanate AS, DiGilio A, Ahn KW, Al Malki M, Jacobsen $E_{1}$ Steinberg $A$ Hamerschlak N, Kharfan-Dabaja M, Salit R, Ball E, Bashir Q, Cashen A, Couriel D, Diez-Martin J, Katsanis E, Linhares $Y$, Mori S, Nash R, Pawarode A, Perales MA, Phipps CD, Richman C, Savani BN, Shapira MY, Stiff P, Strair $R$, Fenske TS, Smith SM, Sureda A, Olteanu $H$, Hamadani M. Allogeneic haematopoietic cell transplantation for extranodal natural killer/T-cell Iymphoma, nasal type: a CIBMTR analysis. Br J Haematol 2018;182:916-920.

20. Li YX, Yao B, Jin J, Wang WH, Liu YP, Song YW, Wang SL, Liu XF, Zhou LQ, He XH, Lu N, Yu ZH. Radiotherapy as primary treatment for stage IE and IIE nasal natural killer/T-cell lymphoma. J Clin Oncol 2006;24:181-189.

21. Cheung MM, Chan JK, Lau WH, Ngan RK, Foo WW. Early stage nasal NK/ T-cell lymphoma: clinical outcome, prognostic factors, and the effect of treatment modality. Int J Radiat Oncol Biol Phys 2002;54:182-190.

22. Lee SH, Ahn YC, Kim WS, Ko YH, Kim K, Park K. The effect of pre-irradiation dose intense CHOP on anthracyline resistance in localized nasal NK/T-cell lymphoma. Haematologica 2006;91:427-428. 
23. Tse E, Chan TS, Koh LP, Chng WJ, Kim WS, Tang T, Lim ST, Lie AK, Kwong YL. Allogeneic haematopoietic SCT for natural killer/T-cell lymphoma: a multicentre analysis from the Asia Lymphoma Study Group. Bone Marrow Transplant 2014;49:902-906.

24. Bi XW, Jiang WQ, Zhang WW, Huang JJ, Xia Y, Wang Y, Sun P, Li ZM. Treatment outcome of patients with advanced stage natural killer/T-cell lymphoma: elucidating the effects of asparaginase and postchemotherapeutic radiotherapy. Ann Hematol 2015;94:1175-1184.

25. Yamaguchi M, Suzuki R, Oguchi M, Asano N, Amaki J, Akiba T, Maeda T, Itasaka S, Kubota N, Saito Y, Kobayashi Y, Itami J, Ueda K, Miyazaki K, li N, Tomita N, Sekiguchi N, Takizawa J, Saito B, Murayama T, Ando T, Wada $H$, Hyo R, Ejima $Y$, Hasegawa M, Katayama N. Treatments and outcomes of patients with extranodal natural killer/T-cell lymphoma diagnosed between 2000 and 2013: a cooperative study in Japan. J Clin Oncol 2017;35:32-39.

26. Su YJ, Wang PN, Chang $H$, Shih LY, Lin TL, Kuo MC, Chuang WY, Wu JH, Tang TC, Hung YS, Dunn P, Kao HW. Extranodal NK/T cell lymphoma, nasal type: clinical features, outcome and prognostic factors in 101 cases. Eur J Haematol 2018;101:379-388.

27. Kim SJ, Yang DH, Kim JS, Kwak JY, Eom HS, Hong DS, Won JH, Lee JH, Yoon DH, Cho J, Nam TK, Lee SW, Ahn YC, Suh C, Kim WS. Concurrent chemoradiotherapy followed byl-asparaginase-containing chemotherapy, VIDL, for localized nasal extranodal NK/T cell lymphoma: CISL08-01 phase II study. Ann Hematol 2014;93:1895-1901.

28. Suzuki R, Suzumiya J, Yamaguchi $M$, Nakamura $S$, Kameoka J, Kojima $H$, Abe M, Kinoshita T, Yoshino T, Iwatsuki K, Kagami Y, Tsuzuki T, Kurokawa M, Ito K, Kawa K, Oshimi K; NK-cell Tumor Study Group. Prognostic factors for mature natural killer (NK) cell neoplasms: aggressive NK cell leukemia and extranodal NK cell lymphoma, nasal type. Ann Oncol 2010;21:1032-1040.

29. Kwong YL. Hematopoietic stem cell transplantation in natural killer cell lymphoma and leukemia. Int J Hematol 2010;92:702-707.

30. Kim HK, Moon SM, Moon JH, Park JE, Byeon S, Kim WS. Complete remission in CD30-positive refractory extranodal NK/T-cell lymphoma with brentuximab vedotin. Blood Res 2015;50:254-256.

31. Kwong YL, Chan TSY, Tan D, Kim SJ, Poon LM, Mow B, Khong PL, Loong F, Au-Yeung R, lqbal J, Phipps C, Tse E. PD1 blockade with pembrolizumab is highly effective in relapsed or refractory NK/T-cell lymphoma failing L-asparaginase. Blood 2017;129:2437-2442.

32. Li M, Gao C, Li H, Wang Z, Cao Y, Huang W, Li X, Wang S, Yu L, Da W. Allogeneic haematopoietic stem cell transplantation as a salvage strategy for relapsed or refractory nasal NK/T-cell lymphoma. Med Oncol 2011;28:840-845.

33. Yagi $T$, Fujino $H$, Hirai $M$, Inoue $T$, Sako $M$, Teshima $H$, Fujii $S$, Hino $M$. Esophageal actinomycosis after allogeneic peripheral blood stem cell transplantation for extranodal natural killer/T cell lymphoma, nasal type. Bone Marrow Transplant 2003;32:451-453.
34. Takenaka $K$, Shinagawa $K$, Maeda $Y$, Makita $M$, Kozuka $T$, Ashiba $A$, Yamamoto K, Fujii N, Nawa Y, Hiramatsu Y, Sunami K, Ishimaru F, Yoshimo T, Kiura K, Harada M. High-dose chemotherapy with hematopoietic stem cell transplantation is effective for nasal and nasal-type CD56+ natural killer cell lymphomas. Leuk Lymphoma 2009;42:1297-1303.

35. Shustov AR, Gooley TA, Sandmaier BM, Shizuru J, Sorror ML, Sahebi $F_{1}$ McSweeney P, Niederwieser D, Bruno B, Storb R, Maloney DG. Allogeneic haematopoietic cell transplantation after nonmyeloablative conditioning in patients with T-cell and natural killer-cell lymphomas. Br J Haematol 2010;150:170-178.

36. Yokoyama H, Yamada MF, Ishizawa K, Yamamoto J, Tomiya $Y$, Harigae $H_{\text {, }}$ Kameoka J, Ichinohasama R, Sasaki T. Successful treatment of advanced extranodal nk/t cell lymphoma with unrelated cord blood transplantation. Tohoku J Exp Med 2007;211:395-399.

37. Ennishi D, Maeda Y, Fujii N, Kondo E, Shinagawa K, Ikeda K, Ichimura K, Yoshino T, Tanimoto M. Allogeneic hematopoietic stem cell transplantation for advanced extranodal natural killer/T-cell lymphoma, nasal type. Leuk Lymphoma 2011;52:1255-1261.

38. Makita $M$, Maeda $Y$, Takenaka $K$, Shinagawa $K$, Sunami $K$, Hiramatsu Y, Fujii N, Ishimaru F, Ikeda K, Niiya K, Yoshino T, Harada M. Successful treatment of progressive $n k$ cell lymphoma with allogeneic peripheral stem cell transplantation followed by early cyclosporine tapering and donor leukocyte infusions. Int J Hematol 2002;76:94-97.

39. Mori Y, Aoki T, Takenaka K, Yamauchi T, Yamamoto A, Kamezaki K, Iwasaki $H$, Harada N. Successful treatment of refractory advanced nasal $\mathrm{NK} / \mathrm{T}$ cell lymphoma with unrelated cord blood stem cell transplantation incorporating focal irradiation. Int J Hematol 2010;91:107-111.

40. Yokoyama $H$, Yamamoto J, Tohmiya $Y$, Yamada MF, Ohguchi H, Ohnishi $Y$ Okitsu Y, Fukuhara N, Ohba-Ohtsuka R, Kohata K, Ishizawa K, Kameoka $\mathrm{J}$, Harigae $\mathrm{H}$. Allogeneic hematopoietic stem cell transplant following chemotherapy containing I-asparaginase as a promising treatment for patients with relapsed or refractory extranodal natural killer/T cell lymphoma, nasal type. Leuk Lymphoma 2010;51:1509-1512.

41. Wakabayashi $S$, Arai A, Oshikawa G, Araki A, Watanabe M, Uchida N, Taniguchi S, Miura 0. Extranodal NK/T cell lymphoma, nasal type, of the small intestine diagnosed by double-balloon endoscopy. Int J Hematol 2009;90:605-610.

42. Czajczynska A, Günther A, Repp R, Humpe A, Schub N, Raff T, Nickelsen M, Schrauder A, Schrappe M, Kneba M, Gramatzki M. Allogeneic stem cell transplantation with BEAM and alemtuzumab conditioning immediately after remission induction has curative potential in advanced T-cell nonHodgkin's lymphoma. Biol Blood Marrow Transplant 2013;19:1632-1637. 


\begin{tabular}{|c|c|c|c|c|c|c|c|c|c|}
\hline $\begin{array}{l}\text { Supplemer } \\
\text { the autho }\end{array}$ & al Tabl & $\begin{array}{l}\text { 1. Detail } \\
\text { ment. }\end{array}$ & & ical featur & s of the 17 & igible reference & reporting 136 patients, and those & f 2 other additi & lal patients from \\
\hline Authors & Year & Country & $\mathbf{n}$ & $\begin{array}{l}\text { Mean or } \\
\text { median } \\
\text { age, years }\end{array}$ & $\begin{array}{l}\text { Sex, male } \\
(\%)\end{array}$ & Clinical stage & Chemotherapy before allo-HSCT & $\begin{array}{l}\text { L-asp-based } \\
\text { chemotherapy } \\
\text { before allo- } \\
\text { HSCT }\end{array}$ & $\begin{array}{l}\text { Radiation } \\
\text { before allo- } \\
\text { HSCT }\end{array}$ \\
\hline $\begin{array}{l}\text { Kanate } \\
\text { et al. [19] }\end{array}$ & 2018 & USA & 82 & 44 & $54(65.8 \%)$ & $\begin{array}{l}\text { I/II: } 35 \\
(42.7 \%) ; I I I / \\
\text { IV: } 22(26.8 \%) ; \\
\text { Unknown: } 25 \\
(30.5 \%)\end{array}$ & $\begin{array}{l}\text { Chemotherapy alone, } 41(50 \%) \text { : CHOP- } \\
\text { or HyperCVAD-like, } 20(24 \%) \text {; DeVIC } \\
\text { or VIPD, } 4(5 \%) \text {; SMILE, } 11(13 \%) \text {; } \\
\text { AspaMetDex, } 2(2 \%) \text {; gemcitabine- } \\
\text { based, } 2(2 \%) \text {; others, } 2(2 \%) \text {. } \\
\text { Chemotherapy + radiation, } 27(32.9 \%) \text { : } \\
\text { CHOP- or HyperCVAD-like + radiation, } \\
14(17 \%) \text {; De-VIC or VIPD + radiation, } \\
8(10 \%) \text {; SMILE + radiation, } 2(2 \%) ; \\
\text { AspaMetDex + radiation, } 2(2 \%) \text {; other } \\
\text { + radiation, } 1(1 \%)\end{array}$ & $31(38 \%)$ & $\begin{array}{l}\text { Chemotherapy } \\
\text { + radiation: } \\
27(32.9 \%) \text {; } \\
\text { Radiation alone: } \\
5(6.1 \%)\end{array}$ \\
\hline $\begin{array}{l}\text { Tse } \\
\text { et al. [23] }\end{array}$ & 2014 & $\begin{array}{l}\text { Hong } \\
\text { Kong, } \\
\text { China }\end{array}$ & 18 & 40.5 & $14(77.8 \%)$ & $\begin{array}{l}\text { I/II:5(27.8\%), } \\
\text { III/IV:13(72.2\%) }\end{array}$ & $\begin{array}{l}\text { SMILE: } 14(78 \%), \text { CHOP: } 2 \text { (11\%), ICE: } 1 \\
(6 \%), \text { CALGB 19802: } 1(6 \%)\end{array}$ & $14(78 \%)$ & $1(6 \%)$ \\
\hline $\begin{array}{l}\text { Li } \\
\text { et al. [32] }\end{array}$ & 2011 & China & 2 & 28.5 & $0.00 \%$ & IIB/IIIB & $\begin{array}{l}\text { BCHOP, CHOPE, ESHAP, MOLP, MINE + } \\
\text { CHOP, BCHOP, MIME, DOLP }\end{array}$ & No & $2(100 \%)$ \\
\hline $\begin{array}{l}\text { Yagi } \\
\text { et al. [33] }\end{array}$ & 2003 & Japan & 1 & 19 & $1(100 \%)$ & Unknown & MACOP-B & No & Yes \\
\hline $\begin{array}{l}\text { Takenaka } \\
\text { et al. [34] }\end{array}$ & 2009 & Japan & 1 & 26 & $0.00 \%$ & I & $\mathrm{EPOCH}$ & No & Yes \\
\hline $\begin{array}{l}\text { Shustov } \\
\text { et al. [35] }\end{array}$ & 2010 & USA & 1 & 63 & $1(100 \%)$ & NE & Unknown & Unknown & Unknown \\
\hline $\begin{array}{l}\text { Suzuki } \\
\text { et al. [7] }\end{array}$ & 2006 & Japan & 6 & 24.8 & $1(16.7 \%)$ & $\begin{array}{l}\text { I/II: } 2(33.3 \%) ; \\
\text { III/IV: } 4 \text { (66.7\%) }\end{array}$ & Unknown & Unknown & Unknown \\
\hline $\begin{array}{l}\text { Yokoyama } \\
\text { et al. [36] }\end{array}$ & 2007 & Japan & 1 & 36 & $0.00 \%$ & IIIB & DeVIC, L-asp/VCR/PSL & Yes & Yes \\
\hline $\begin{array}{l}\text { Ennishi } \\
\text { et al. [37] }\end{array}$ & 2011 & Japan & 12 & 28 & $5(41.7 \%)$ & $\begin{array}{l}\text { I/II: } 4(33.3 \%) ; \\
\text { III/IV: } 8(66.7 \%)\end{array}$ & $\begin{array}{l}\text { CHOP + MEPP, CHOP + MINE, EPOCH, } \\
\text { CHOP + DeVIC + EPOCH, DeVIC + } \\
\text { EPOCH, SMILE, CHOP, DeVIC + SMILE, } \\
\text { SMILE, SMILE + DeVIC, DeVIC + HD- } \\
\text { Ara-C, DeVIC + SMILE }\end{array}$ & $5(41.7 \%)$ & $4(33.3 \%)$ \\
\hline $\begin{array}{l}\text { Allo-HSCT: } \\
\text { disease (a: } \\
\text { conditionin }\end{array}$ & gene & hemato & . & em cell tr & $\begin{array}{l}\text { splantation; } \\
\text {; PR: partial }\end{array}$ & sp: L-asparagine & $\begin{array}{l}\text {; PFS: progression-free survival; OS: ov } \\
\text { essive disease; RIC: reduced-intensity co }\end{array}$ & $\begin{array}{l}\text { all survival; GVH } \\
\text { ditioning regime }\end{array}$ & $\begin{array}{l}\text { graft-versus-host } \\
\text { MC: myeloablative }\end{array}$ \\
\hline
\end{tabular}




\begin{tabular}{|c|c|c|c|c|c|c|c|c|c|c|}
\hline $\begin{array}{l}\text { Time from } \\
\text { diagnosis to } \\
\text { allo-HSCT }\end{array}$ & $\begin{array}{l}\text { Disease status at } \\
\text { transplantation }\end{array}$ & $\begin{array}{l}\text { Conditioning } \\
\text { regimens }\end{array}$ & $\begin{array}{l}\text { Regimen } \\
\text { intensity }\end{array}$ & $\begin{array}{l}\text { Source of } \\
\text { hematopoietic } \\
\text { stem cells }\end{array}$ & $\begin{array}{l}\text { Donor } \\
\text { matching }\end{array}$ & PFS & OS & $\begin{array}{l}\text { Rate of } \\
\text { relapse }\end{array}$ & Result & GVHD \\
\hline Unknown & $\begin{array}{l}\text { CR: } 37(45 \%), \\
\text { PR: } 25(30 \%), \\
\text { chemorefractory: } \\
10(12 \%), \\
\text { untreated/ } \\
\text { unknown: } 10 \\
(12 \%)\end{array}$ & Unknown & $\begin{array}{l}\text { RIC: } 48 \\
(59 \%), \mathrm{MC}: \\
31(38 \%), \\
\text { Unknown: } \\
3(4 \%)\end{array}$ & $\begin{array}{l}\text { BM: } 4(5 \%), \\
\text { PBSC: } 73 \\
(89.0 \%), \text { CB: } 5 \\
(6 \%)\end{array}$ & $\begin{array}{l}\text { Matched-related } \\
\text { donor: } 50 \\
(61 \%), \text { unrelated } \\
\text { donor: } 23(28 \%), \\
\text { umbilical cord } \\
\text { blood: } 5(6 \%), \\
\text { haploidentical- } \\
\text { related donor: } 3 \\
(4 \%), \text { unknown: } \\
1(1 \%)\end{array}$ & $\begin{array}{l}28 \% \\
\text { (3-year } \\
\text { PFS) }\end{array}$ & $\begin{array}{l}34 \% \\
\text { (3-year } \\
\text { OS) }\end{array}$ & $\begin{array}{l}34 \\
\text { patients } \\
(42 \%) \\
\text { relapsed }\end{array}$ & $\begin{array}{l}52 \text { patients } \\
(63.4 \%) \text { died }\end{array}$ & $\begin{array}{l}\text { aGVHD: } \\
29(40 \%), \\
\text { 2-year } \\
\text { cGVHD: } 29 \\
(40 \%)\end{array}$ \\
\hline Unknown & $\begin{array}{l}\text { CR: } 16(88.9 \%) \\
\left(\mathrm{CR}_{1}, \mathrm{n}=9 ; \mathrm{CR}_{2}\right. \\
\mathrm{n=7}), \mathrm{PR}: 1(6 \%), \\
\text { PD: } 1(6 \%)\end{array}$ & $\begin{array}{l}\text { CY/TBI: } 8 \\
\text { (44\%), CY/ } \\
\text { TBI/anti- } \\
\text { thymocyte } \\
\text { globulin: } \\
1(6 \%), \\
\text { etoposide/ } \\
\text { TBI: } 1(6 \%), \\
\text { TBI: } 1(6 \%) \text {, } \\
\text { CY/BCNU/ } \\
\text { etoposide: } 2 \\
\text { (11\%), BU/ } \\
\text { CY: } 1(6 \%), \\
\text { fludarabine/ } \\
\text { melphalan: } 4 \\
\text { (22\%) }\end{array}$ & $\begin{array}{l}\text { RIC: } 4 \\
(22.2 \%), \\
\text { MC: } 14 \\
(77.8 \%)\end{array}$ & $\begin{array}{l}\text { BM: } 7 \text { (39\%), } \\
\text { PBSC: } 11 \\
(61.1 \%)\end{array}$ & $\begin{array}{l}\text { Matched-related } \\
\text { donor: } 12 \\
(67 \%), \text { matched- } \\
\text { unrelated donor: } \\
6(33 \%)\end{array}$ & $\begin{array}{l}51 \% \\
\text { (5-year } \\
\text { PFS) }\end{array}$ & $\begin{array}{l}57 \% \\
(5-\text { year } \\
\text { OS) }\end{array}$ & $\begin{array}{l}5 \\
\text { patients } \\
(27.8 \%) \\
\text { relapsed }\end{array}$ & $\begin{array}{l}8 \text { patients } \\
(44.4 \%) \text { died }\end{array}$ & $\begin{array}{l}\text { aGVHD: } 9 \\
\text { (grade } 1-2 \text { : } \\
n=7, \text { grade } \\
3-4: n=2 \text { ), } \\
\text { cGVHD: } \\
\text { 4(mild: } \\
n=3 ; \\
\text { severe: } \\
n=1 \text { ) }\end{array}$ \\
\hline $\begin{array}{l}18 \text { months/ } \\
\text { Unknown }\end{array}$ & $\begin{array}{l}\text { Relapse, PR2/ } \\
\text { Non-CR }\end{array}$ & $\begin{array}{l}\mathrm{BU} / \mathrm{CY} / \mathrm{Vm} 26 / \\
\mathrm{Ara}-\mathrm{C} ; \mathrm{BU} / \\
\mathrm{CY} / \mathrm{MeCCNu} / \\
\text { Ara-C }\end{array}$ & $\begin{array}{l}\text { MC: } 2 \\
(100 \%)\end{array}$ & $\begin{array}{l}\text { PBSC: } 2 \\
(100 \%)\end{array}$ & $\begin{array}{l}\text { Matched-related } \\
\text { donor: } 2(100 \%)\end{array}$ & $\begin{array}{l}100 \% \\
\text { (3-year } \\
\text { PFS) }\end{array}$ & $\begin{array}{l}100 \% \\
\text { (3-year } \\
\text { OS) }\end{array}$ & 0 & $\begin{array}{l}\text { CR and alive } \\
\text { for } 3 \text { years } \\
\text { and } 5 \text { years, } \\
\text { respectively }\end{array}$ & $\begin{array}{l}\text { No aGVHD } \\
\text { or cGVHD }\end{array}$ \\
\hline 6 months & Non-CR & BU/CY/VP16 & $\mathrm{MC}$ & PBSC & $\begin{array}{l}\text { Haploidentical- } \\
\text { related donor }\end{array}$ & & & 0 & $\begin{array}{l}\text { CR and } \\
\text { alive for } 18 \\
\text { months }\end{array}$ & $\begin{array}{l}\text { aGVHD: } \\
\text { grade II, } \\
\text { cGVHD: } \\
\text { mild oral } \\
\text { mucosa }\end{array}$ \\
\hline 5 months & PR & $\mathrm{TBI} / \mathrm{CY}$ & $\mathrm{MC}$ & PBSC & $\begin{array}{l}\text { Matched-related } \\
\text { donor }\end{array}$ & & & 0 & $\begin{array}{l}\text { CR and } \\
\text { alive for } 11 \\
\text { months }\end{array}$ & $\begin{array}{l}\text { No aGVHD } \\
\text { or cGVHD }\end{array}$ \\
\hline 9 months & CR & TBI + Flu & RIC & NE & $\begin{array}{l}\text { Matched-related } \\
\text { donor }\end{array}$ & & & 0 & $\begin{array}{l}\text { CR and alive } \\
\text { for } 49.1 \\
\text { months }\end{array}$ & $\begin{array}{l}\text { No aGVHD } \\
\text { or cGVHD }\end{array}$ \\
\hline 6.3 months & $\begin{array}{l}\mathrm{CR}_{2}: 1(16.7 \%), \\
1^{\text {st }} \text { relapse: } 2 \\
(33.3 \%), \text { primary } \\
\text { refractory: } 3 \\
(50 \%)\end{array}$ & $\begin{array}{l}\text { Unknown + } \\
\text { TBI }\end{array}$ & $\begin{array}{l}\text { MC: } 6 \\
(100 \%)\end{array}$ & $\begin{array}{l}\text { BM: } 3(50 \%) \\
\text { PBSC: } 3(50 \%)\end{array}$ & $\begin{array}{l}\text { Matched- } \\
\text { related donor: } \\
5(83.3 \%) \text {, } \\
\text { matched- } \\
\text { unrelated donor: } \\
1(16.7 \%)\end{array}$ & $\begin{array}{l}50 \% \\
\text { (3-year } \\
\text { PFS) }\end{array}$ & $\begin{array}{l}50 \% \\
\text { (3-year } \\
\text { OS) }\end{array}$ & $\begin{array}{l}1 \text { patient } \\
(16.7 \%) \\
\text { relapsed }\end{array}$ & $\begin{array}{l}3 \text { patients } \\
(50 \%) \text { died; } \\
\text { the other } 3 \\
\text { patients CR } \\
\text { and alive for } \\
30+, 56+, \\
78+\text { months, } \\
\text { respectively }\end{array}$ & Unknown \\
\hline Unknown & $\begin{array}{l}\text { Recurrence, not } \\
\text { CR }\end{array}$ & $\begin{array}{l}\text { TBI + Ara-C } \\
+ \text { CTX }\end{array}$ & $\mathrm{MC}$ & CB & CB & & & 0 & $\begin{array}{l}\text { CR and } \\
\text { alive for } 33 \\
\text { months }\end{array}$ & $\begin{array}{l}\text { aGVHD: } \\
\text { gut, grade } \\
\text { l; cGVHD: } \\
\text { oral } \\
\text { mucosa }\end{array}$ \\
\hline 6 months & $\begin{array}{l}\text { CR: } 4(33.3 \%) \\
\left.\text { (CR }: 2, \mathrm{CR}_{2}: 2\right)_{1} \\
\text { PR: } 4(33.3 \%), \text { PD: } \\
4(33.3 \%)\end{array}$ & $\begin{array}{l}\text { CY + TBI: } 8 \\
(66.7 \%), F l u \\
+ \text { CY + TBI: } \\
3(25 \%), \text { CA } \\
+ \text { CY + TBI: } 1 \\
(8.3 \%)\end{array}$ & $\begin{array}{l}\text { RIC: } 3 \\
(25 \%), M C: \\
9(75 \%)\end{array}$ & $\begin{array}{l}\text { BM: } 4 \text { (33.3\%), } \\
\text { PBSC: } 3(25 \%), \\
\text { CB: } 5 \text { (41.7\%) }\end{array}$ & Unknown & $\begin{array}{l}53 \% \\
\text { (3-year } \\
\text { PFS) }\end{array}$ & $\begin{array}{l}55 \% \\
\text { (3-year } \\
\text { OS) }\end{array}$ & $\begin{array}{l}4 \\
\text { patients } \\
(33.3 \%) \\
\text { relapsed }\end{array}$ & $\begin{array}{l}5 \text { patients } \\
\text { died }\end{array}$ & $\begin{array}{l}\text { aGVHD } \\
(\mathrm{I}, \mathrm{II}): 6 \\
(50 \%), \\
\text { cGVHD: } 1 \\
(8.3 \%)\end{array}$ \\
\hline
\end{tabular}




\begin{tabular}{|c|c|c|c|c|c|c|c|c|c|}
\hline Authors & Year & Country & $\mathbf{n}$ & $\begin{array}{l}\text { Mean or } \\
\text { median } \\
\text { age, years }\end{array}$ & $\begin{array}{l}\text { Sex, male } \\
(\%)\end{array}$ & Clinical stage & Chemotherapy before allo-HSCT & $\begin{array}{l}\text { L-asp-based } \\
\text { chemotherapy } \\
\text { before allo- } \\
\text { HSCT }\end{array}$ & $\begin{array}{l}\text { Radiation } \\
\text { before allo- } \\
\text { HSCT }\end{array}$ \\
\hline Ito et al. [11] & 2011 & Japan & 1 & 29 & $1(100 \%)$ & IIE & CHOP, DeVIC & No & Yes \\
\hline $\begin{array}{l}\text { Makita } \\
\text { et al. [38] }\end{array}$ & 2002 & Japan & 1 & 26 & $0.00 \%$ & Unknown & $\mathrm{EPOCH}$ & No & Yes \\
\hline $\begin{array}{l}\text { Mori } \\
\text { et al. [39] }\end{array}$ & 2010 & Japan & 1 & 52 & $0.00 \%$ & IVB & $\begin{array}{l}\text { Dexamethasone + methotrexate } \\
+ \text { ifosfamide }+ \text { L-asparaginase + } \\
\text { etoposide/DeVIC }\end{array}$ & Yes & Yes \\
\hline $\begin{array}{l}\text { Matsuo } \\
\text { et al. [10] }\end{array}$ & 2015 & Japan & 1 & 55 & $1(100 \%)$ & Unknown & SMILE & Yes & No \\
\hline $\begin{array}{l}\text { Yokoyama } \\
\text { et al. [40] }\end{array}$ & 2010 & Japan & 5 & 31 & $3(60 \%)$ & 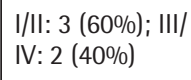 & $\begin{array}{l}\text { DeVIC, L-asp, DeVIC, CHOP + MCVC } \\
\text { + auto-PBSCT, CHOP }\end{array}$ & $1(20 \%)$ & $3(60 \%)$ \\
\hline $\begin{array}{l}\text { Kako } \\
\text { et al. [12] }\end{array}$ & 2007 & Japan & 1 & 43 & $0.00 \%$ & IV & $\begin{array}{l}\text { HyperCVAD/MA + dexamethasone, } \\
\text { etoposide, ifosphamide, and } \\
\text { carboplatin }\end{array}$ & No & No \\
\hline $\begin{array}{l}\text { Wakabayashi } \\
\text { et al. [41] }\end{array}$ & 2009 & Japan & 1 & 47 & $1(100 \%)$ & IVB & DeVIC & No & No \\
\hline $\begin{array}{l}\text { Czajczynska } \\
\text { et al. [42] }\end{array}$ & 2013 & Germany & 1 & 11 & $1(100 \%)$ & Unknown & CLAEG & No & Unknown \\
\hline $\begin{array}{l}\text { Authors' } \\
\text { department }\end{array}$ & & China & 2 & 37 & $1(50 \%)$ & IVB & CHOP + SMILE, GLIDE + MTX & $2(100 \%)$ & No \\
\hline
\end{tabular}




\begin{tabular}{|c|c|c|c|c|c|c|c|c|c|c|}
\hline $\begin{array}{l}\text { Time from } \\
\text { diagnosis to } \\
\text { allo-HSCT }\end{array}$ & $\begin{array}{l}\text { Disease status at } \\
\text { transplantation }\end{array}$ & $\begin{array}{l}\text { Conditioning } \\
\text { regimens }\end{array}$ & $\begin{array}{l}\text { Regimen } \\
\text { intensity }\end{array}$ & $\begin{array}{l}\text { Source of } \\
\text { hematopoietic } \\
\text { stem cells }\end{array}$ & $\begin{array}{l}\text { Donor } \\
\text { matching }\end{array}$ & PFS & OS & $\begin{array}{l}\text { Rate of } \\
\text { relapse }\end{array}$ & Result & GVHD \\
\hline Unknown & Recurrence & $\mathrm{CY}+\mathrm{TBI}$ & MC & BM & $\begin{array}{l}\text { Matched-related } \\
\text { donor }\end{array}$ & & & $\begin{array}{l}\text { Relapsed } \\
\text { locally }\end{array}$ & $\begin{array}{l}\text { CR and alive } \\
\text { for } 4 \text { years }\end{array}$ & $\begin{array}{l}\text { cGVHD: } \\
\text { skin and } \\
\text { liver }\end{array}$ \\
\hline Unknown & PD & $\mathrm{CY}+\mathrm{TBI}$ & MC & PBSC & $\begin{array}{l}\text { Matched-related } \\
\text { donor }\end{array}$ & & & 0 & $\begin{array}{l}\text { CR and alive } \\
\text { for } 2 \text { years }\end{array}$ & $\begin{array}{l}\text { cGVHD: } \\
\text { oral } \\
\text { mucosa } \\
\text { and liver }\end{array}$ \\
\hline 7 months & PD & $\mathrm{CY}+\mathrm{TBI}$ & $\mathrm{MC}$ & CB & CB & & & 0 & $\begin{array}{l}\mathrm{CR} \text { and } \\
\text { alive for } 18 \\
\text { months }\end{array}$ & $\begin{array}{l}\text { aGVHD: } \\
\text { skin (grade } \\
\text { 3), cGVHD: } \\
\text { skin and } \\
\text { pericardial } \\
\text { effusion }\end{array}$ \\
\hline $\begin{array}{l}4 \text { months, } 9 \\
\text { months }\end{array}$ & Non-CR & $\mathrm{MC} / \mathrm{RIC}$ & $\mathrm{MC} / \mathrm{RIC}$ & PBSC & & & & Relapsed & Died & $\begin{array}{l}\text { aGVHD: } \\
\text { skin }\end{array}$ \\
\hline Unknown & $\begin{array}{l}\text { Relapse and } \\
\mathrm{CR}_{2}: 3(60 \%), \\
\text { refractory: } 1 \\
(20 \%), \text { relapse: } 1 \\
(20 \%)\end{array}$ & $\begin{array}{l}\mathrm{CA} / \mathrm{CY} / \mathrm{TBI}, \mathrm{TBI} / \\
\mathrm{CY}, \mathrm{CA} / \mathrm{CY} / \mathrm{TBI}, \\
\mathrm{CY} / \mathrm{TBI}, \mathrm{CA} / \\
\mathrm{CY} / \mathrm{TBI}\end{array}$ & $\begin{array}{l}\text { MC: } 5 \\
(100 \%)\end{array}$ & $\begin{array}{l}\text { BM: } 3(60 \%), \\
\text { CB: } 2(40 \%)\end{array}$ & $\begin{array}{l}\text { Matched-related } \\
\text { donor: } 2(40 \%), \\
\text { CB: } 2(40 \%), \\
\text { unknown: } 1 \\
(20 \%)\end{array}$ & $\begin{array}{l}60 \% \\
\text { (3-year } \\
\text { PFS) }\end{array}$ & $\begin{array}{l}60 \% \\
\text { (3-year } \\
\text { OS) }\end{array}$ & 0 & $\begin{array}{l}\text { CR and alive } \\
\text { for median } \\
\text { follow-up } \\
\text { time of } 1911 \\
\text { days (range: } \\
888-2617 \\
\text { days) }\end{array}$ & $\begin{array}{l}\text { aGVHD: } \\
2 \text { (40\%), } \\
\text { cGVHD: } 3 \\
(60 \%)\end{array}$ \\
\hline Unknown & Relapse & $\mathrm{CY}+\mathrm{TBI}$ & $\mathrm{MC}$ & PBSC & $\begin{array}{l}\text { Haploidentical- } \\
\text { related donor }\end{array}$ & & & $\begin{array}{l}\text { Relapsed } \\
\text { locally }\end{array}$ & $\begin{array}{l}\text { CR and alive } \\
\text { for more } \\
\text { than } 1 \text { year }\end{array}$ & $\begin{array}{l}\text { aGVHD } \\
\text { (grade II) } \\
\text { of skin, } \\
\text { cGVHD of } \\
\text { liver }\end{array}$ \\
\hline 6 months & CR & $\begin{array}{l}\text { Fludarabine } \\
+ \text { melphalan } \\
+\mathrm{TBI}\end{array}$ & $\mathrm{RIC}$ & BM & $\begin{array}{l}\text { Matched- } \\
\text { unrelated donor }\end{array}$ & & & Relapsed & Died & $\begin{array}{l}\text { No aGVHD } \\
\text { or cGVHD }\end{array}$ \\
\hline Unknown & PR & $\begin{array}{l}\text { BEAM/Cam } \\
\text { (alemtuzumab) }\end{array}$ & $\mathrm{MC}$ & PBSC & $\begin{array}{l}\text { Haploidentical- } \\
\text { related donor }\end{array}$ & & & 0 & $\begin{array}{l}\text { CR and alive } \\
\text { for } 1400 \\
\text { days }\end{array}$ & $\begin{array}{l}\text { aGVHD } \\
\text { (grade II), } \\
\text { no cGVHD }\end{array}$ \\
\hline $\begin{array}{l}3 \text { months, } 5 \\
\text { months }\end{array}$ & PR-CR, PR & $\begin{array}{l}\text { IBUCY, FLAG + } \\
\text { BUCY }\end{array}$ & $\mathrm{MC}$ & PBSC & $\begin{array}{l}\text { Matched-related } \\
\text { donor: } 2(100 \%)\end{array}$ & & & 0 & $\begin{array}{l}\text { CR and } \\
\text { alive for } 66 \\
\text { months and } \\
50 \text { months, } \\
\text { respectively }\end{array}$ & $\begin{array}{l}\text { No aGVHD } \\
\text { or cGVHD }\end{array}$ \\
\hline
\end{tabular}

